\title{
Пенсионная система в современной России: реформа за реформой...
}

Н.П. ДЕМЕНТЬЕВ, доктор физико-математических наук, Институт экономики и организации промышленного производства СО РАН, Новосибирск.

E-mail: dement@ieie.nsc.ru

Аннотация. В последние годы в России был принят ряд законов, существенно изменивших институциональную структуру национальной пенсионной системы (акционирование пенсионных фондов, создание системы гарантирования пенсионных накоплений, замораживание накопительных пенсий). Кроме того, в конце 2018 г. вступил в силу весьма спорный закон о повышении пенсионного возраста, а в настоящее время Банком России и Минфином РФ подготовлен законопроект о создании добровольной системы индивидуального пенсионного капитала.

На основе сопоставления ключевых демографических и пенсионных показателей в России и странах Организации экономического сотрудничества и развития (ОЭСР) автор делает вывод, что для недавнего повышения пенсионного возраста в России (для мужчин, в особенности) не было веских оснований. Подвергнуты сомнению утверждения сторонников этого законопроекта о чрезмерных трансфертах федерального бюджета системе обязательного пенсионного страхования. Исходя из предшествующего опыта в пенсионной сфере РФ, предпринята попытка оценить, насколько принятые законы поддержат рост сбережений населения в добровольных пенсионных схемах. Показано, в частности, что в ближайшие годы проектируемая система индивидуального пенсионного капитала лишь частично сможет заменить пенсионные накопления на рынке длинных денег.

Ключевые слова: обязательное пенсионное страхование; реформа; негосударственные пенсионные фонды; индивидуальный пенсионный капитал; стареющее население; пенсионный возраст

В современной России сосуществуют три вида пенсий: трудовые пенсии в системе обязательного пенсионного страхования (ОПС, объем выплат в 2017 г. составил 6378 млрд руб.), пенсии в системе государственного пенсионного обеспечения (пенсии военным и государственным служащим, социальные пенсии и т.п. - 433 млрд руб.) и частные пенсии в системе негосударственного пенсионного обеспечения (НПО - 60 млрд руб.).

История современной системы ОПС начинается с пенсионной реформы 2002 г., результатом которой стал переход от распределительной системы ОПС к системе с условно-накопительными

\footnotetext{
${ }^{1}$ Статья подготовлена по плану НИР ИЭОПП СО РАН, проект ХІ.170. 1.1. «Инновационные и экологические аспекты структурной трансформации российской экономики в условиях новой геополитической реальности», № AАAА-А17-117022250127-8.
} 
и накопительными элементами (накопительная пенсия предусматривалась только для граждан, родившихся после 1966 г.). Условно-накопительный элемент подразумевает, что часть пенсионных взносов идет на выплату текущих пенсий, а на индивидуальных счетах застрахованных накапливаются не реальные деньги, а обязательства государства по выплате будущих пенсий.

В основу реформы были заложены рекомендации Всемирного банка, разработанные им в начале 1990-х гг. для пенсионных систем развивающихся стран. Реформа в России долго готовилась, и поначалу Государственная дума возражала против введения в систему ОПС накопительной пенсии. Аргументация ее экспертов [Новиков, 2001] была простой: в стране с неустойчивыми экономикой и финансовой системой нельзя принуждать население делать пенсионные накопления, бо́льшая часть которых наверняка обесценится в результате инфляции и неэффективной инвестиционной политики пенсионных фондов. Примерно в то же время появились работы известных экономистов [Orszag, Stiglitz, 1999; Barr, 2001], показывавших, что большинство утверждений о преимуществах накопительных пенсионных систем не доказано ни теоретически, ни практически.

До 2014 г. система ОПС концептуально менялась мало, хотя ее отдельные элементы и параметры (тарифы пенсионных взносов, минимальный рабочий стаж, формула расчета пенсий и пр.) многократно пересматривались. При этом, насколько можно судить, властями преследовались две основные цели. Во-первых, пенсии в России были и остаются низкими по мировым меркам, и с этим нужно что-то делать. Во-вторых, в правительстве считают, что трансферты из федерального бюджета на обязательное пенсионное страхование чрезмерны, и их следует сократить. Однако череда не всегда продуманных корректировок российской пенсионной системы не повышала ее эффективность, а лишь снижала доверие к ней со стороны населения (нельзя доверять долгосрочные сбережения системе, в которой правила игры постоянно меняются).

В мире существует множество хорошо работающих пенсионных систем разного типа. Важно, чтобы тип системы отвечал реалиям страны. Причина же российских неудач в поисках повышения эффективности пенсионной системы состоит в том, что вне зависимости от ее типа трудно обеспечить достойные пенсии в стране со стагнирующей экономикой, неустойчивой финансовой 
системой, слабой налоговой дисциплиной, громадным выводом капитала за рубеж и низкими доходами населения. Тем не менее, как мы видим, поиски «чудодейственной» пенсионной системы продолжаются.

На декабрь 2013 г. пришелся пик в пенсионном законотворчестве, предопределивший изменения в пенсионной сфере на несколько лет вперед. Были приняты законы ${ }^{2}$ об акционировании негосударственных пенсионных фондов и о создании системы гарантирования пенсионных накоплений. Их цель - сделать деятельность НПФ более прозрачной для Банка России и повысить устойчивость накопительной составляющей пенсии.

Тогда же, в декабре, был принят закон ${ }^{3}$, по которому граждане 1967 г. рождения и моложе должны были подтвердить намерение и дальше отчислять средства на накопительную пенсию, иначе их взносы целиком пойдут на формирование страховой пенсии. Кроме того, в 2014 г. было решено заморозить накопительные пенсионные взносы. Как говорилось в годовом отчете ПФР за 2014 г., «на время преобразований введена законодательная приостановка новых обязательных отчислений на накопительную часть пенсии - все страховые взносы в 2014 году направлялись на формирование страховой части трудовой пенсии». Затем, однако, заморозка из года в год продлевалась, и в обозримом будущем накопительные взносы едва ли будут восстановлены.

Еще в 2016 г. Минфин и Банк России предложили вообще ликвидировать накопительную часть в системе ОПС и одновременно создать добровольную систему индивидуального пенсионного капитала (ИПК). К настоящему времени соответствующий законопроект ими подготовлен, но официально не опубликован (хотя основные положения его известны и активно обсуждаются в открытой печати).

\footnotetext{
${ }^{2}$ Ф3 № 410-Ф3 «О внесении изменений в Федеральный закон “О негосударственных пенсионных фондах” и отдельные законодательные акты Российской Федерации» от 28.12 .2013 г.

Ф3 № 422-Ф3 «О гарантировании прав застрахованных лиц в системе обязательного пенсионного страхования Российской Федерации при формировании и инвестировании средств пенсионных накоплений, установлении и осуществлении выплат за счет средств пенсионных накоплений» от 28.12.2013.

${ }^{3}$ Ф3 № 351-Ф3 «О внесении изменений в отдельные законодательные акты Российской Федерации по вопросам обязательного пенсионного страхования в части права выбора застрахованными лицами варианта пенсионного обеспечения» от 04.12.2013.
} 
Наконец, 3 октября 2018 г. был принят закон о повышении возраста выхода на пенсию до 65 лет для мужчин и до 60 лет для женщин. Этот закон негативно был воспринят населением России, чему были объективные причины. В последние годы появилось немало работ по пенсионной проблематике, авторов которых можно с некоторой долей условности поделить на сторонников и противников повышения пенсионного возраста. К числу первых относятся, в частности, экономисты, имеющие или имевшие отношение к Минфину. По их мнению, без повышения пенсионного возраста экономический рост в России замедлится и, главное, федеральный бюджет окажется под угрозой кризиса из-за его чрезмерных трансфертов пенсионной системе [Гурвич, Сонина, 2012; Кудрин, Гурвич, 2012; Гурвич, Иванова, 2018]. Вторую группу составляют экономисты, считающие, что демографическая ситуация и состояние здоровья населения не дают оснований для повышения пенсионного возраста [Вишневский и др., 2012; Аганбегян, 2015; Синявская, 2017; Горлин и др., 2018; Щетинина, 2018; Любинин, 2018].

В этой статье затронутые выше вопросы рассматриваются более подробно. Акцент сделан на анализ и сравнение основных показателей и параметров пенсионных систем в России и странах ОЭСР, публикующих подробную статистику по пенсионной проблематике. На основе уже накопленного опыта в пенсионной сфере РФ предпринята попытка оценить, поспособствуют ли принятые законы росту сбережений населения в добровольных пенсионных схемах. Кроме пенсионной и демографической статистики Росстата, Банка России, ПФР и российских НПФ, использовались также данные ООН, ОЭСР, Евростата и Всемирного банка.

\section{Так ли уж велики трансферты федерального бюджета системе ОПС?}

Согласно годовому отчету ПФР, в 2017 г. пенсионные взносы в системе ОПС составили 4482 млрд руб., а объем выплаченных страховых пенсий - 6378 млрд руб. Дефицит (2072 млрд руб.) был покрыт за счет трансфертов из федерального бюджета. Следует, однако, отметить, что более трети последней суммы составили средства на финансирование государственных льгот в виде досрочного выхода на пенсию (313 млрд руб.) и пониженных тарифов 
страховых взносов (434 млрд руб.). Такие затраты федерального бюджета лишь условно можно считать дотациями системе ОПС.

Среди лиц, имеющих право на досрочный выход на пенсию, можно выделить две основные группы. Первую составляют лица, отработавшие определенное количество лет на рабочих местах с вредными и опасными условиями труда, а вторую представители ряда профессий, которым это право предоставляется по выслуге лет (это большей частью учителя и врачи).

Практика финансирования государством досрочного выхода на пенсию работников на вредных и опасных производствах вызывает немало вопросов. Действительно, в рыночной экономике издержки, связанные с досрочными пенсиями, логично возложить на работодателей. Финансирование таких издержек государством является, по сути, трансфертом не пенсионной системе, а корпорациям. У последних к тому же ослабляются стимулы к модернизации вредных производств, что составляет дополнительный минус системы такого спонсирования. Впрочем, здесь происходят позитивные изменения: ныне в зависимости от степени вредности и опасности условий труда действуют дополнительные тарифы пенсионных взносов - от 0 до $8 \%$ от заработной платы. Что же касается учителей и врачей, то работодателем для большинства из них является государство, потому оно и должно нести издержки, связанные с правом на досрочную пенсию.

Аналогичным образом государство предоставляет право на пониженные страховые взносы некоторым компаниям из сферы информационных технологий и из особых экономических зон. Например, для резидентов проекта «Сколково» тариф пенсионных взносов равен $14 \%$ (вместо 22\%), для IT-компаний - $8 \%$, для резидентов особых экономических зон $-6 \%{ }^{4}$. Финансирование подобных льгот - это элемент политики государства по стимулированию инновационной деятельности, а потому именно оно, а не пенсионная система, должно такую политику оплачивать.

Итак, в 2017 г. трансферты федерального бюджета системе ОПС за вычетом указанных выше дотаций, можно оценить в 1325 (2072-747) млрд руб., что составляет 20,8\% от выплаченных страховых пенсий. Это не критичный объем. В Германии,

${ }^{4}$ URL: https://buhguru.com/strahovie-vznosy/stavki-ponizh-tarif-strah-vznos.html (дата обращения: 17.04.2019). 
например, в 2015 г. государственные дотации составили около $50 \%$ доходов общенационального пенсионного страхового фонда ${ }^{5}$. Разумеется, в России и Германии сравнивать доли государства в финансировании пенсий следует осторожно, ведь пенсионные системы в них различаются. Однако в России данный показатель настолько ниже, что трансферты федерального бюджета на финансирование страховых пенсий едва ли можно считать чрезмерными.

Вообще, на фоне стран Евросоюза государственные социальные расходы в России, в которые включаются и пенсионные трансферты, выглядят намного скромнее. Так, по информации Росстата, в 2015 г. денежные социальные пособия в расходах сектора «Государственное управление» составляли $10,8 \%$ от ВВП, тогда как аналогичные расходы стран Евросоюза - в среднем $15,8 \%$ (данные Евростата). Так что уверения Минфина о том, что система ОПС обходится федеральному бюджету слишком дорого и потому пенсионный возраст следует увеличить, выглядят не слишком убедительными. Как отмечалось в работе А. Соловьева [Соловьев, 2015], повышение пенсионного возраста должно быть направлено на стимулирование формирования пенсионных прав застрахованных в долгосрочной перспективе, «а не на умозрительную экономию средств государственного бюджета».

\section{Повышение пенсионного возраста}

в демографическом и экономическом контексте

Предложения о повышении в России пенсионного возраста выдвигались в структурах Минфина РФ задолго до принятия соответствующего закона. Так, например, в работах [Гурвич, Сонина, 2012; Кудрин, Гурвич, 2012] были исследованы проблемы старения населения в России и связанные с ними угрозы для экономики и государственного бюджета и сделаны выводы о необходимости повышения пенсионного возраста. Дескать, «чем раньше это произойдет, тем лучше и для пенсионеров, и для налогоплательщиков, и для страны в целом, поскольку рано или поздно придется пойти по этому пути» [Кудрин, Гурвич, 2012].

При этом в статьях ничего не говорилось о том, что при 60-летнем пенсионном возрасте до пенсии не доживал каждый

${ }^{5}$ URL: https://pensiya-lgoty.ru/pensionnaya-sistema-v-germanii/ (дата обращения: 17.04.2019). 
третий российский мужчина, а после его повышения таковых окажется намного больше. Лишь в 2018 г., когда вопрос о повышении пенсионного возраста уже был практически решен, авторы работы [Гурвич, Иванова, 2018] свои выводы о его необходимости снабдили оговоркой: если повышение «обосновано с точки зрения демографических показателей и состояния здоровья населения».

Возникает вопрос, учитывались ли в должной мере демографические условия в ходе обсуждения и принятия закона о повышении пенсионного возраста? Исследования российских демографов убеждают, скорее, в обратном. Так, О.В. Синявская, сопоставив демографические показатели в России и других странах, сделала вывод «о возможности рассматривать повышение пенсионного возраста для женщин, но не для мужчин» [Синявская, 2017]. Столь же определенно высказывались ее коллеги из Института социального анализа и прогнозирования: «... демографический потенциал повышения пенсионного возраста для мужчин крайне ограничен ... имеется определенный демографический потенциал повышения пенсионного возраста в отношении женщин» [Горлин и др., 2018]. Схожие выводы на основе анализа демографической динамики в России (с привлечением показателей продолжительности здоровой жизни) были сделаны в работах А. Вишневского и др. [Вишневский и др., 2012; Аганбегян, 2015]: демографических оснований для повышения пенсионного возраста нет, сначала необходимо увеличить продолжительность здоровой жизни населения.

Проведенный ниже сравнительный анализ пенсионных и демографических показателей в России и странах ОЭСР подтверждает правоту противников повышения пенсионного возраста в России. В ходе анализа были примерно оценены доли пенсионных выплат отдельно мужчинам и женщинам в доходах всего населения в России и странах ОЭСР.

В 2016 г. в России пенсионный возраст для мужчин составлял 60 лет, а для мужчин из стран ОЭСР - в среднем 65,8 года (табл. 1). Несмотря на почти шестилетнюю разницу в пенсионном возрасте, в России только 65,9\% мужчин могли в тот год дожить до пенсии, тогда как в странах ОЭСР - около 83,8\%. В России средняя продолжительность жизни пенсионеровмужчин (от 60 лет) была равна 15,5 года, а в странах ОЭСР 
аналогичный показатель (от 65 лет) - 18,2 года. Кроме того, в России чистый коэффициент замещения пенсией утраченного заработка для мужчин в 2016 г. составлял 38,8\%, а странах ОЭСР - 62,9\% (а с учетом пенсий в добровольных пенсионных схемах - 69,1\%). Итак, по каждому из приведенных ключевых показателей положение российских пенсионеров-мужчин было намного хуже, чем в странах ОЭСР. И это даже при прежнем 60-летнем пенсионном возрасте.

\section{Таблица 1. Демографические и пенсионные показатели в России и странах ОЭСР, 2016 г.}

\begin{tabular}{|c|c|c|c|c|}
\hline \multirow{2}{*}{$\begin{array}{c}\text { Демографические и пенсионные } \\
\text { показатели }\end{array}$} & \multicolumn{2}{|c|}{ Женщины } & \multicolumn{2}{|c|}{ Мужчины } \\
\hline & Россия & ОЭСР & Россия & OЭСР \\
\hline \multicolumn{5}{|l|}{ Средняя продолжительность жизни, лет } \\
\hline от рождения & 76,8 & 83,4 & 65,6 & 78,3 \\
\hline от 60 лет & 21,0 & $(23,9)$ & 15,5 & $(19,9)$ \\
\hline от 65 лет & 17,6 & 21,3 & 13,1 & 18,2 \\
\hline Вероятность дожития от рождения до 60 лет,\% & 86,5 & $(91,9)$ & 65,9 & $(82,0)$ \\
\hline Вероятность дожития от рождения до 65 лет,\% & 82,5 & 90,7 & 57,2 & 83,8 \\
\hline $\begin{array}{l}\text { Пенсионный возраст (для ОЭСР - в среднем } \\
\text { по странам), лет }\end{array}$ & 55,0 & 65,5 & 60,0 & 65,8 \\
\hline Валовой коэффициент замещения,\% & 28,6 & 52,3 & 33,7 & 52,9 \\
\hline $\begin{array}{l}\text { Валовой коэффициент замещения с учетом до- } \\
\text { бровольных пенсионных схем,\% }\end{array}$ & $\cdots$ & $\ldots$ & 33,7 & 58,7 \\
\hline Чистый коэффициент замещения,\% & 32,9 & 62,2 & 38,8 & 62,9 \\
\hline $\begin{array}{l}\text { Чистый коэффициент замещения с учетом добро- } \\
\text { вольных пенсионных схем,\% }\end{array}$ & $\ldots$ & $\cdots$ & 38,8 & 69,1 \\
\hline
\end{tabular}

Источник: таблица составлена большей частью по данным доклада ОЭСР о пенсионных системах в странах ОЭСР и группы G20, вышедшего в 2017 г. Pensions at a Glance 2017. OECD and G20 Indicators. DOI.org/10.1787/pension_glance-2017en. Сведения о вероятности дожития от рождения до 60 лет взяты из статистики $\mathrm{OOH}$. United Nations. World Population Prospects 2017. Mortality indicators. URL: https://population.un.org/wpp/Download/Standard/Mortality/ (дата обращения: 22.03. 2019)., а до 65 лет - из статистики Всемирного банка. The World Bank. Survival to age 65, female (\% of cohort). URL: https://data.worldbank.org/indicator/ SP.DYN.TO65.FE.ZS (дата обращения: 22.03. 2019). The World Bank. Survival to age 65 , male (\% of cohort). URL: https://data.worldbank.org/indicator/SP.DYN. TO65.MA.ZS (дата обращения: 22.03. 2019).

Примечание: Цифры в скобках относятся к Европе в целом. Ожидаемая продолжительность жизни людей определяется как число лет, которое они в среднем могли быпрожить, если бынапротяжении этихлет соблюдалисьтеже возрастные иполовые коэффициенты смертности, что ив 2015-2020 гг. Валовой коэффициент замещенияпенсиейутраченногозаработкарассчитывается какотношениеназначенной пенсии к предпенсионному заработку. Чистый коэффициент замещения отличается от валового учетом выплачиваемых работниками и пенсионерами подоходных налогов и взносов в систему социального обеспечения. 
После повышения пенсионного возраста до 65 лет вероятность дожития российских мужчин до пенсии снижается до $57,2 \%$, средняя продолжительность жизни от 65 лет до 13,1 года, и разница в положении мужчин-пенсионеров в России и странах ОЭСР становится совсем уж чрезмерной.

О том же свидетельствуют и показатели старения населения в России и странах ОЭСР. Коэффициент старения населения определяется в статистике ОЭСР как число лиц старше 65 лет, приходящихся на 100 лиц в возрасте от 20 до 64 лет. Согласно докладу ОЭСР о пенсионных системах в странах ОЭСР и G20 за 2017 г., в 2015 г. такой коэффициент в России был равен 20,7, тогда как в странах ОЭСР - 27,9.

На основе статистики Росстата и $\mathrm{OOH}$ по распределению населения по полу и возрасту в странах мира ${ }^{6}$ можно рассчитать пропорции между численностями мужчин и женщин старше 65 лет в России и странах ОЭСР - 10:21 и 10:13 соответственно. Следовательно, после повышения пенсионного возраста следует ожидать, что в России на 1000 граждан в возрасте от 20 до 64 лет будет приходиться 67 мужчин-пенсионеров $(67 \approx 207 /$ $(1+2,1))$, тогда как в странах ОЭСР $-121(121 \approx 279 /(1+1,13)$, т.е. в 1,8 раза больше.

Кроме того, уровень замещения пенсией утраченного заработка для российских мужчин в 1,6 раза ниже, чем в странах ОЭСР (с учетом участия в добровольных пенсионных схемах в 1,8 раза ниже). Прикидочные расчеты показывают, что доля мужских пенсий в доходах населения России будет примерно в три раза ниже по сравнению с аналогичным показателем в странах ОЭСР.

Несколько лучше в России обстоят дела с пенсиями для женщин. Судя по таблице 1, при пенсионном возрасте в 60 лет вероятность дожития российских женщин до пенсии равна $86,5 \%$, что сопоставимо с показателями ОЭСР. Действительно, в странах ОЭСР средний пенсионный возраст для женщин - 65,5 года, а вероятность дожития до 65 лет равна 90,7\%.

\footnotetext{
${ }^{6}$ ФСГС. Демография. URL: http://www.gks.ru/wps/wcm/connect/rosstat_main/rosstat/ru/ statistics/population/demography/\# (дата обращения: 07.05.2019); Demographic Yearbook, 2015. United Nations. New York. URL:

https://unstats.un.org/unsd/demographic-social/products/dyb/dybsets/2015.pdf (дата обращения: 07.05.2019).
} 
Средняя продолжительность жизни женщин-пенсионерок (от 60 лет в России и от 65 странах ОЭСР) почти одинакова 21 год и 21,3 года. Но по чистому коэффициенту замещения пенсией утраченного заработка женщины России почти в два раза уступают женщинам в странах ОЭСР - соответственно 32,9 и $62,2 \%$. Так что после повышения пенсионного возраста доля пенсий российских женщин в доходах всего населения страны окажется ниже в сравнении с аналогичным показателем в странах ОЭСР. Хотя, конечно, разрыв здесь не столь значителен, как у мужчин.

В России широко распространена практика теневых зарплат, что снижает доходы Пенсионного фонда России. Как заявил А. Силуанов в ноябре 2017 г., «от четверти до трети зарплат находятся в “серой” зоне»”. Стало быть, лишь 67-75\% потенциальных пенсионных взносов поступает в систему ОПС (вот где следовало бы искать резервы для повышения пенсий). После повышения пенсионного возраста вывод зарплат в «тень» наверняка еще более расширится. Это выгодно работодателям, а что до молодых мужчин, то они едва ли будут сильно беспокоиться о своей будущей пенсии, ведь около $40 \%$ из них все равно до нее не доживет. Возникает вопрос, возможно ли снижение явно завышенных пенсионных возрастов в России (пусть и не до прежних уровней). Выглядит это невероятным, хотя подобный прецедент имел место в Польше. Там в 2013 г. пенсионный возраст для обоих полов подняли до 67 лет, но уже в 2016 г. вернулись к прежним параметрам: 65 лет для мужчин и 60 - для женщин.

При одинаковых пенсионных возрастах в России и Польше между ними есть большие демографические различия: если россиянин доживет до 65 лет с вероятностью в 57\%, то полякс вероятностью в 76\%; если россиянин будет жить после 65 лет в среднем 13,1 года, то поляк - 17,5 года. Конечно, мы отдаем себе отчет в том, что в России повышение пенсионного возраста растянуто на пять лет, но, как показывает статистика, демографические показатели медленно изменяются во времени.

${ }^{7}$ URL: https://finance.rambler.ru/money/38532281-do-treti-zarplat-rossiyan-nahodyatsyav-seroy-zone/ (дата обращения: 03.06.2019). 


\section{Банк России ужесточает контроль над пенсионными фондами}

Одной из причин появления в конце 2013 г. законов об акционировании НПФ и о системе гарантирования пенсионных накоплений была низкая доходность последних (см., например [Дементьев, 2015]). На протяжении 2008-2014 гг. она составляла в НПФ в среднем 5\% годовых, тогда как потребительские цены росли в среднем на $8,8 \%$ за год. Для будущих пенсионеров делать накопления при такой доходности не имеет смысла.

Отметим, что при нынешней структуре инвестирования пенсионных накоплений их доходность в принципе не может быть высокой. По данным Банка России, на 31 декабря 2018 г. структура совокупных активов четырех крупнейших НПФ, на которые приходился $71 \%$ всех пенсионных накоплений, имела следующий вид: долговые ценные бумаги $-86 \%$, акции $-7,5 \%$, денежные средства $-6,5 \%$. Ясно, что только акции могли иметь доходность, существенно превышающую банковский процент по депозитам, но их доля в активах недостаточна, чтобы существенно повлиять на совокупные показатели фонда.

Низкая доходность пенсионных накоплений связана также с тем, что многие НПФ озабочены в первую очередь интересами своих учредителей, а не клиентов. Нередко банки открывают пенсионные фонды и привлеченные пенсионные средства инвестируют в свои же активы по завышенной цене. Хотя на такие операции закон накладывает ограничения, их нередко обходили путем формально законных перекрестных инвестиций между финансовыми структурами. Так, например, по словам Э. Набиуллиной ${ }^{8}$, до недавнего времени существовало «московское банковское кольцо», в которое входили банки и пенсионные фонды. В 2017 г. банки «кольца» прямо или косвенно контролировали шесть НПФ («ЛУКОЙЛ-ГАРАНТ», «БУДУЩЕЕ», «САФМАР», «РГС», «Доверие» и «НПФ электроэнергетики»), в которых было сосредоточено около половины всех пенсионных накоплений. Чтобы обойти ограничения Центробанка, внутри «кольца» проводились перекрестные операции.

В 2017 г. большие трудности стали испытывать два банка из «кольца» (ФК «Открытие» и Бинбанк). Спасла их лишь

\footnotetext{
${ }^{8}$ Ведомости. 2018. 6 июня. С. 1.
} 
санация со стороны Банка России, который не мог допустить краха системообразующих организаций. Все шесть НПФ при этом понесли потери: пенсионные накопления в них имели в 2017-2018 гг. отрицательную доходность. В результате в 2018 г. средневзвешенная доходность пенсионных накоплений во всех НПФ составила $0,1 \%$ (и это до вычета административных издержек) $)^{9}$.

Согласно закону об акционировании, до конца 2015 г. все НПФ, работающие в системе ОПС, должны были быть преобразованы из некоммерческих организаций в акционерные общества (последние более жестко контролируются Банком России). НПФ, работающие только в системе негосударственного пенсионного обеспечения (НПО), должны были пройти процедуру акционирования до конца 2018 г. Одновременно ужесточались требования по размеру собственных средств и уставного капитала (не менее 150 и 120 млрд руб. соответственно), по прозрачности информации о физических лицах, контролирующих решения акционеров руководителей НПФ, по квалификации руководителей фондов и т.д. Кроме того, акционерным НПФ запрещается выплачивать дивиденды по акциям в течение пяти лет со дня их регистрации. Некоторые фонды не прошли «экзамен», некоторые объединились, и к концу 2018 г. число НПФ снизилось до 52, тогда как на 31 декабря 2013 г. их было 120.

НПФ, работающие с пенсионными накоплениями и прошедшие акционирование, должны войти в систему гарантирования пенсионных накоплений. Данная система состоит из двух уровней. Первый составляют собственные резервы пенсионных фондов, а второй - Фонд гарантирования пенсионных накоплений (ФГПН), формирующийся за счет обязательных взносов пенсионных фондов (до принятия закона о системе гарантирования пенсионных накоплений в конце 2013 г. второго уровня гарантий не было). ФГПН управляется Агентством по страхованию вкладов (АСВ), которое гарантирует стопроцентную сохранность взносов на накопительную пенсию. Обычно утверждается, что система гарантирования пенсионных накоплений является аналогом страхования банковских вкладов. Однако это верно лишь

\footnotetext{
${ }^{9}$ Банк России. Обзор финансовой стабильности. IV квартал 2018 года. I квартал 2019 года. URL: https://www.cbr.ru/Collection/Collection/File/19790/OFS_19-01.pdf (дата обращения: 04.06.2019).
} 
отчасти. Если в случае банкротства банка АСВ гарантирует возврат вкладов вместе с процентными доходами (до 1,4 млн руб.), то после отзыва лицензии у пенсионного фонда возмещаются лишь номинальные накопительные взносы (без инвестиционного дохода). Стало быть, по сравнению с банковскими вкладами риски пенсионных накоплений более высоки. Если система накопительных пенсий будет сохранена, то гарантии ФГПН наверняка подвигнут фонды к расширению инвестиций в более доходные, но и более рискованные активы, в корпоративные акции, прежде всего.

\section{Перспективы индивидуального пенсионного капитала}

С предложением о создании системы индивидуального капитала (ИПК) Банк России и Минфин выступили еще в 2016 г., но до сих пор в ее деталях нет полной определенности. Не вполне ясно, что будет с системой накопительных пенсий в рамках ОПС, но почти наверняка можно утверждать, что в ближайшие годы она будет либо ликвидирована (при этом неясно, что будет с уже существующими пенсионными накоплениями), либо оставаться в замороженном состоянии. По недавним словам А. Силуанова ${ }^{10}$, законопроект о системе индивидуального пенсионного капитала уже готов, но его опубликование и обсуждение были отложены из-за негативной реакции в стране на закон о повышении пенсионного возраста. Все же выступления должностных лиц Минфина, Банка России, Минтруда и ПФР дают довольно полное представление об основных положениях законопроекта.

Предполагается, что обязательные взносы в систему ОПС останутся на прежнем уровне в $22 \%$ от заработной платы, и все они пойдут на выплату текущих страховых пенсий. Тем самым система ОПС станет полностью условно-накопительной. По желанию работающие могут участвовать в системе ИПК и отчислять в НПФ из своей заработной платы от 0 до 6\%. После выхода на пенсию участник ИПК может сразу забрать свои сбережения либо получать их частями в последующие годы. Если в пенсионном плане участника не предполагаются пожизненные

${ }^{10}$ ЦБ сообщил о скором начале обсуждения новой пенсионной концепции. URL: https://www.rbc.ru/rbcfreenews/5c3df4d89a79471fbb6ef5db (дата обращения: 04.06.2019). 
выплаты, то в случае его смерти остатки накопленного капитала достанутся его наследникам. В экстраординарных случаях (жизненно необходимые медицинские расходы, например) можно будет воспользоваться капиталом и до выхода на пенсию.

В качестве стимулирующей меры предполагается не взимать НДФЛ с той части заработной платы, которая отчисляется в систему ИПК. Кроме того, на средства участников системы ИПК будет распространен тот же страховой механизм, что действует для пенсионных накоплений: АСВ будет гарантировать возврат взносов, но без инвестиционного дохода.

С. Швецов, первый зампредседателя Банка России, считает, что система ИПК соберет 10 трлн руб. за десять лет, если она «будет запущена в широкомасштабном формате» ${ }^{11}$. Весьма оптимистичен и А. Силуанов, по словам которого, внедрение ИПК прибавит к пенсии до $20 \%$ от среднемесячной зарплаты ${ }^{12}$.

Предполагаемую ликвидацию пенсионных накоплений в системе ОПС можно рассматривать как исправление ошибки пенсионной реформы 2002 г., на которую еще при подготовке реформы указывали в Госдуме. Нечто подобное уже сделали в Венгрии, Польше, Чехии и некоторых латиноамериканских странах, где полностью или частично отказались от введенных ранее обязательных пенсионных накоплений. В то же время нет оснований считать, что система ИПК может стать полноценным заменителем пенсионных накоплений на рынке «длинных» денег. Приведенные выше прогнозы С. Швецова и А. Силуанова выглядят явно несбыточными. На это указывает хотя бы опыт добровольной Программы государственного софинансирования пенсий.

Как известно, в Программе накопительные взносы граждан (в размере от 2 до 12 тыс. руб. за год) удваиваются государством, что, конечно же, не в пример выгоднее налоговых льгот в проектируемой системе ИПК. Тем не менее результаты Программы оказались мизерными: за 2009-2017 гг. взносы ее участников составили всего лишь 56,4 млрд руб. Непонятно, почему российские граждане и их работодатели захотят массово участвовать в системе ИПК, если они фактически проигнорировали более

\footnotetext{
${ }^{11}$ Усов И. Пенсионной системе готовят три «П» // Коммерсант. 2018. 21 мая. С. 8.

${ }^{12}$ Силуанов рассказал о способе увеличить пенсию на $20 \%$ от зарплаты. URL:

https://www.vestifinance.ru/videos/46974 (дата обращения: 04.06.2019).
} 
привлекательную программу софинансирования. О том же свидетельствует стагнация существующей системы НПО в России (более подробно в следующем разделе статьи), безразличие большей части населения («молчунов») к своей накопительной пенсии, его нежелание участвовать в другом виде коллективных инвестиций - в паевых инвестиционных фондах [Дементьев, 2017]. К тому же банковские вклады и сбережения в государственных ценных бумагах имеют минимальные риски, а по доходности не уступают средствам в пенсионных фондах.

Итак, в ближайшие годы от введения системы ИПК едва ли стоит ожидать значительных изменений в финансовой и пенсионной сфере России. Основная масса населения проигнорирует ее так же, как она это сделала с Программой государственного софинансирования пенсий. Скорее всего, крупные монополии переведут часть корпоративных пенсий из обычного формата в систему ИПК, но это окажется перекладыванием пенсионных средств из одной структуры в другую. Предполагаемая система ИПК отчасти следует опыту государственного стимулирования сбережений населения США в частных пенсионных программах, но там для этого существуют намного более благоприятные условия. Сказанное не означает, что систему ИПК не следует вводить: добровольные пенсионные сбережения надо поощрять в любом случае. Если в ближайшие годы экономика России начнет, наконец, стабильно развиваться, то через 5-10 лет результаты системы ИПК могут оказаться ощутимыми.

\section{Проблемы негосударственного пенсионного обеспечения}

Напомним, на 31декабря 2018 г. в России действовало 52 негосударственных пенсионных фонда. Из них 17 фондов работали только в рамках системы НПО, 2 - только в рамках системы ОПС, и 33 - в обеих системах. Согласно таблице 2, пенсионные накопления в НПФ составляли 2582 млрд руб., а пенсионные резервы - 1268 млрд руб. ${ }^{13}$ В таблице представлены фонды с активами свыше 100 млрд руб. Совокупный объем их активов равен 3559 млрд руб., или 87,7\% от активов всех НПФ. Это

\footnotetext{
${ }^{13}$ Пенсионные накопления и пенсионные резервы в НПФ формируются для обеспечения обязательств перед застрахованными в системе ОПС и участниками системы НПО, соответственно.
} 
свидетельство высокой концентрации и низкой конкуренции в пенсионной сфере России.

Особенно высока концентрация в системе НПО, где выделяются два лидера - «ГАЗФОНД» и «БЛАГОСОСТОЯНИЕ». Первый из них обслуживает большей частью корпоративные пенсионные программы для работников ПАО «Газпром». Треть работников в газовой отрасли - будущие получатели корпоративных пенсий в этом фонде ${ }^{14}$. Основная специализация НПФ «БЛАГОСОСТОЯНИЕ»-пенсионное обеспечение работников холдинга «Российские железные дороги». В его корпоративных программах участвуют около 660 тыс. железнодорожников ${ }^{15}$. На 30 сентября 2018 г. пенсионные резервы в обоих фондах составляли 793 млрд руб. (62,5\% в пенсионных резервах всех НПФ).

\section{Таблица 2. Основные показатели деятельности НПФ на 31 декабря 2018 г.}

\begin{tabular}{|l|c|c|c|c|c|}
\hline $\begin{array}{l}\text { Негосударствен- } \\
\text { ный пенсионный } \\
\text { фонд }\end{array}$ & $\begin{array}{c}\text { Активы, } \\
\text { млн руб. }\end{array}$ & $\begin{array}{c}\text { Пенсионные } \\
\text { резервы, } \\
\text { млн руб. }\end{array}$ & $\begin{array}{c}\text { Количество } \\
\text { участников } \\
\text { нпо, чел. }\end{array}$ & $\begin{array}{c}\text { Пенсионные } \\
\text { накопления, } \\
\text { млн руб. }\end{array}$ & $\begin{array}{c}\text { Количество } \\
\text { застрахован- } \\
\text { ных, чел. }\end{array}$ \\
\hline Все НПФ & 4056957 & 1267959 & 6131624 & 2582323 & 36973256 \\
\hline В том числе: & & & & & \\
\hline НПФ Сбербанка & 627149 & 37718 & 1752035 & 573509 & 8855165 \\
\hline «Открытие» & 564937 & 63996 & 540826 & 492990 & 7415120 \\
\hline $\begin{array}{l}\text { «ГАЗФОНД пенсион- } \\
\text { ные накопления» }\end{array}$ & 541409 & 18964 & 160505 & 505785 & 6325739 \\
\hline «ГАЗФОНД» & 477483 & 386805 & 233020 & 0 & 0 \\
\hline «БЛАГОСОСТОЯНИЕ» & 407632 & 379841 & 1298137 & 0 & 0 \\
\hline «БУДУЩЕЕ» & 268032 & 3370 & 73792 & 262197 & 4502671 \\
\hline $\begin{array}{l}\text { ВТБ Пенсионный } \\
\text { фОНД }\end{array}$ & 200019 & 4297 & 65214 & 191830 & 2120615 \\
\hline «НЕТТГАРАНТ» & 192674 & 65901 & 160383 & 120664 & 1530433 \\
\hline «САФМАР» & 177631 & 8018 & 76680 & 165023 & 2163200 \\
\hline «Транснефть» & 101711 & 89352 & 143124 & 9426 & 49321 \\
\hline
\end{tabular}

Источник: ЦБ РФ. Субъекты рынка коллективных инвестиций. URL: https://www. cbr.ru/finmarket/supervision/sv_coll/ (дата обращения: 09.04.2019).

На 30 сентября 2018 г. в фондах «ГАЗФОНД», «Транснефть», «НЕФТЕГАРАНТ» пенсионные резервы в расчете на одного

\footnotetext{
${ }^{14}$ Корпоративная программа ПАО «Газпром». URL: https:/gazfond.ru/corporate/ gazprom/ (дата обращения: 27.05.2019).

${ }^{15}$ Корпоративная пенсионная система холдинга «РЖД». URL: http://npfb.ru/cotrudnikam-rzhd/ (дата обращения: 27.05.2019).
} 
участника НПО составляли в среднем 1046 тыс. руб., а в НПФ «БЛАГОСОСТОЯНИЕ»-298 тыс. руб. В остальных же фондах, на которые приходилось $70,1 \%$ всех участников НПО, аналогичный показатель был равен символическим 74 тыс. руб.

Как видим, система НПО обслуживает в основном корпоративные пенсионные программы нескольких крупных монополий. Прочие предприятия и просто физические лица проявляют к ней мало интереса. Поэтому в последние годы система НПО находится в стагнации: за 2012-2018 гг. количество ее участников сократилось с 6,6 до 6,1 млн чел., а пенсионные резервы в реальном выражении (с учетом официального роста потребительских цен) росли в течение этого периода в среднем на $1,7 \%$ за год. И это притом, что в Налоговом кодексе РФ предусмотрены льготы для стимулирования добровольного пенсионного страхования. Взносы физического лица в систему НПО (до 120 тыс. руб. в год) вычитаются из налоговой базы по НДФЛ. Если работодатель участвует в пенсионных программах своих работников, то его взносы, не превышающие $12 \%$ от оплаты труда, уменьшают базу по налогу на прибыль.

Причины непопулярности добровольных пенсионных программ хорошо известны: невысокие доходы подавляющего числа граждан России, низкая инвестиционная доходность пенсионных средств и, особенно - недоверие населения к финансовой системе вообще и пенсионным фондам в частности. По данным Банка России ${ }^{16}$, на 30 сентября 2018 г. доля активов без рейтинга и с высоким риском в совокупном портфеле пенсионных резервов была равна 28\%, что негативно сказывалось на его доходности. За первое полугодие 2018 г. она составила 5,4\% годовых (до вычета вознаграждения фондам, управляющим компаниям и специализированным депозитариям).

В то же время пенсионные накопления в НПФ довольно быстро росли. За 2012-2018 гг. их объем вырос с 394 до 2582 млрд руб., а число застрахованных в НПФ (по системе ОПС) - с 11,9 до 37 млн чел. Факторами роста были принудительные накопления населения (до 2014 г.), инвестиционные доходы и, главное - переход застрахованных со своими накоплениями

\footnotetext{
${ }^{16}$ Банк России. Обзор финансовой стабильности. II-III кварталы 2018 года. URL: https://www.cbr.ru/Collection/Collection/File/10438/OFS_18-02.pdf (дата обращения: 04.06.2019).
} 
из Пенсионного фонда России в негосударственные пенсионные фонды.

В России потенциал добровольного пенсионного страхования сильно переоценивается властями. Частные пенсионные планы (программы) действительно широко распространены в некоторых странах с передовой экономикой и высокоразвитым фондовым рынком. В США, например, около половины привлеченных средств частные пенсионные фонды напрямую или через взаимные фонды инвестируют в корпоративные акции, которые на протяжении многих лет быстро росли в цене и тем самым обеспечивали программам очень высокую доходность. Именно с этим связано широкое участие населения в различных пенсионных программах на протяжении последних четырех десятилетий.

В большинстве других стран роль частного пенсионного страхования в инвестиционных процессах и пенсионном обеспечении населения намного скромнее. По данным ОЭСР, на конец 2016 г. в четырех «англосаксонских» странах (США, Великобритания, Канада, Австралия) активы частных пенсионных планов составляли 31,2 трлн долл. (в США - 25,1 трлн долл.), тогда как в остальных 31 странах - участницах этой организации - всего лишь 6,9 трлн долл.

Выше указывалось, что в ОЭСР коэффициент замещения утраченного заработка пенсией составлял $62,9 \%$, а с учетом добровольных пенсионных схем - 69,1\%. Это означает, что пенсии, получаемые из систем обязательного страхования, примерно в 10 раз превышают пенсии, получаемые по добровольному страхованию. В России с ее скромной экономикой и множеством институциональных «несовершенств» тем более нельзя ожидать сколько-нибудь быстрого развития добровольного пенсионного страхования в ближайшие годы.

\section{Краткие выводы}

Вызывает большие сомнения утверждение о том, что трансферты федерального бюджета системе обязательного пенсионного страхования слишком велики. Более трети из них связаны не с теми или иными недостатками системы ОПС, а с государственной политикой в виде финансирования досрочного выхода на пенсию отдельных категорий работников либо пониженных 
тарифов страховых взносов. Такие льготы представляют собой дотирование государством некоторых видов экономической деятельности, а потому оно и должно их оплачивать.

Сопоставление демографических и пенсионных показателей в России и странах ОЭСР свидетельствует о том, что для недавнего резкого повышения пенсионного возраста не было веских оснований (для мужчин, в особенности). По трем ключевым показателям (вероятность дожития до пенсии, средняя продолжительность жизни в пенсионном возрасте, коэффициент замещения пенсией утраченного заработка) российские мужчины-пенсионеры и до повышения пенсионного возраста намного уступали мужчинам из стран ОЭСР, а после повышения разрыв стал совсем уж критическим. На основе коэффициентов старения и статистики распределения населения по полу и возрасту был сделан вывод, что после повышения пенсионного возраста в России доля мужских пенсий в доходах всего населения будет примерно в три раза ниже, чем в странах ОЭСР. По тому же показателю российские женщины также будут значительно уступать женщинам в странах ОЭСР (хотя и не столь сильно, как мужчины).

По многим причинам (стагнация в экономике, неустойчивая финансовая система, неэффективная и, порой, недобросовестная инвестиционная политика пенсионных фондов и пр.) пенсионные средства имеют низкую инвестиционную доходность. На этом фоне акционирование НПФ, создание системы гарантирования пенсионных накоплений, заморозка системы накопительных пенсий с ее вероятной ликвидацией в будущем - вполне обоснованные меры. Вместе с тем в ближайшие годы проектируемая Банком России и Минфином добровольная система индивидуального пенсионного капитала едва ли окажет скольконибудь значительное влияние на пенсионную сферу, на рынок «длинных» денег. Она будет просто проигнорирована основной частью населения, как это ранее произошло с гораздо более выгодной Программой государственного софинансирования пенсии. Нужны устойчивые изменения к лучшему в экономике и финансовой сфере, а также время, чтобы население изменило укоренившееся негативное отношение к добровольным пенсионным сбережениям. 
Что же касается системы негосударственного пенсионного обеспечения, она по-прежнему обслуживает большей частью корпоративные пенсионные программы нефтегазовых монополий и холдинга «РЖД». В ближайшем будущем нет оснований ожидать быстрого развития системы НПО.

\section{Литература}

Аганбегян А.Г. О продолжительности здоровой жизни в пенсионном возрасте // ЭКО. 2015. № 7. С. 144-157.

Вишневский А., Васин С., Рамонов А. Возраст выхода на пенсию и продолжительность жизни // Вопросы экономики. 2012. № 9. С. 88-109.

Горлин Ю.М., Ляшок В. Ю., Малева Т. М. Повышение пенсионного возраста: позитивные эффекты и вероятные риски // Экономическая политика. 2018.Т. 13. № 1. C. $148-149$.

Гурвич Е., Сонина Ю. Микроанализ российской пенсионной системы // Вопросы экономики. 2012. № 2. С. 27-51.

Гурвич Е.Т., Иванова М.А. Экономический эффект старения населения и пенсионных реформ // Финансовый журнал. 2018. № 5. С. 9-22.

Дементьев Н.П. Пенсионная система в современной России: перманентное реформирование и неопределенность // ЭКО. 2015. № 11. С. 153-168.

Дементьев Н.П. Российские паевые инвестиционные фонды: закрытые общества миллионеров // ЭКО. 2017. № 9. С. 176-189.

Новиков А. И. Зарубежные пенсионные системы: опыт для России. Аналитический вестник Государственной думы РФ. 2001. Вып. 16. URL: http://iam. duma.gov.ru/node/8/4533 (дата обращения: 29.05.2019).

Кудрин А., Гурвич Е. Старение населения и угроза бюджетного кризиса // Вопросы экономики. 2012. № 3. С. 52-79.

Любинин А.Б. Пенсионная реформа: из «тени» в «тень»// Российский экономический журнал. 2018. № 5. С. 26-42.

Синявская О.В. Российская пенсионная система в контексте демографических вызовов и ограничений // Экономический журнал «Высшей школы экономики». 2017. Т. 21. № 4. С. 562-591.

Соловьев А. Повышение пенсионного возраста: демографические условия и макроэкономические риски // Экономист. 2015. № 7. С. 3-12.

Щетинина И.В. Повышение пенсионного возраста: аргументы «за» и «против» // ЭКО.2018. № 11. С. 96-115.

Barr N. The Truth About Pension Reform // Finance\&Development. IMF, 2001, Vol. 38. № 3. URL: http://www.imf.org/external/pubs/ft/fandd/2001/09/barr.htm (дата обращения: 15.05.2019).

Orszag P.R., Stiglitz J.E. Rethinking Pension Reform: Ten Myths About Social Security Systems. URL: http://www.ssc.wisc.edu/ scholz/Teaching_742/OrszagStiglitz.pdf (дата обращения: 15.05.2019). 
Для цитирования: Дементьев Н.П. Пенсионная система в современной России: реформа за реформой...// ЭКО. 2019. № 8. С. 9-30. DOI: 10.30680/ ECO0131-7652-2019-8-9-30.

Статья поступила 14.06.2019.

\section{Summary}

Dementiev, N.P., Doct. Sci. (Physics and Mathematics), Institute of Economics and Industrial Engineering, SB RAS, Novosibirsk

\section{Pension system in modern Russia: reform after reform...}

Abstract. As of late, Russia passed a number of laws that substantially affected the insti-tutional framework of the national pension system (corporatization of pension funds, retirement savings security system design, freezing of funded pensions). A very controversial law raising the retirement age was enacted in late 2018. Further, the Bank of Russia and the Ministry of Finance drafted a bill to establish a voluntary system of individual pension capital.

The comparison of key demographic and pension indicators in Russia and in the Organi-zation for Economic Cooperation and Development (OECD) countries concluded that there are no compelling reasons for the recent raising of retirement age in Russia (especially for men). The claims of new retirement age supporters about excessive federal budget transfers to the mandato-ry pension insurance are questioned. Drawing on the previous experience of the national pension sector, an attempt is made to estimate whether the enacted laws will sustain the growth of per-sonal savings in voluntary pension schemes. Particularly, it is shown that the designed system of individual pension capital will only partially be able to replace mandatory retirement savings in the long money market in the coming years.

Keywords: mandatory pension insurance, funded pension systems, reform, private pension funds, individual pension capital, ageing population, retirement age

\section{References}

Aganbegyan, A.G. (2015). About Healthy Life Expectancy and Pension Age. ECO. No. 7. Pp. 144-157. (In Russ.).

Barr, N. (2001). The Truth About Pension Reform. Finance\&Development. IMF. Vol. 38. No. 3. Avalable at: http://www.imf.org/external/pubs/ft/fandd/2001/09/barr. htm (accessed 15.05.2019).

Dementiev, N.P. (2015). Pension System in Modern Russia: Permanent Reforming and Uncertainty. ECO. No. 11. Pp. 153-168. (In Russ.).

Dementiev, N.P. (2017). Russian Unit Investment Funds: Closet Companies of Millionaires. ECO. No. 9. Pp. 176-189. (In Russ.).

Gorlin, Yu.M., Lyashok, V.Yu., Maleva, T.M. (2018). Pension Age Increase: Positive Effects and the Possible Risks. Economic Policy. No. 1. Pp. 148-179. (In Russ.).

Gurvich, E., Sonina, Yu. (2012). Microanalisis of the Russia's pension system. Voprosy Ekonomiki. No. 2. Pp. 27-51. (In Russ.).

Gurvich, E. T. Ivanova, M.A. (2018). Economic Effect of Population Ageing and Pension Reforms. Financial Journal. No. 5. Pp. 9-22. (In Russ.). 
Kudrin, A., Gurvich, E. (2012). Population aging and risks of budget crisis. Voprosy Ekonomiki. No. 3. Pp. 52-79. (In Russ.).

Lyubinin, A.B. (2018). Pension Reform: From "Shadow" to "Shadow"... Russian Economic Journal. No. 5. Pp. 26-42. (In Russ.).

Novikov, A.I. (2001). Foreign pension systems: experience for Russia. Analytical Bulletin of the State Duma of the Russian Federation. Vol. 16. (In Russ.). Available at: http://iam.duma.gov.ru/node/8/4533 (accessed 15.05.2019).

Orszag, P.R., Stiglitz, J.E. (1999). Rethinking Pension Reform: Ten Myths About Social Security Systems. Available at: http://www.ssc.wisc.edu/ scholz/ Teaching_742/Orszag-Stiglitz.pdf (accessed 15.05.2019)

Sinyavskaya, O.V. (2017). Russian Pension System in the Context of Demographic Challenges and Constraints. Higher School of Economics Economic Journal. No. 4. Pp. 562-591. (In Russ.).

Solov'ev, A. (2015). Increasing the Retirement Age: Demographic Conditions and Macroeconomic Risk. Economist. No. 7. Pp. 3-12. (In Russ.).

Shchetinina, I.V. (2018). Increasing the Retirement Age: Point for and Against. ECO. No. 11. Pp. 96-115. (In Russ.).

Vishnevsky, A., Vasin, S., Ramonov, A. (2012). Retirement Age and Life Expectancy in the Russian Federation. Voprosy Ekonomiki. No. 9. Pp. 88-109. (In Russ.).

For citation: Dementiev, N.P. (2019). Pension System in Modern Russia: Reform by Reform... ECO. No. 8. Pp. 9-30. (In Russ.). DOI: 10.30680/ECO01317652-2019-8-9-30. 